\title{
Obituary
}

\section{Helena Avelar de Carvalho (17 September 1964-9 March 2021)}

Helena Avelar de Carvalho died suddenly on 9 March 2021. She had established herself as an authority on the practice of astrology in Western Europe but, sadly, was not able to see the publication of her article on predicting the length of life that is published in this issue of IJDP nor the substantial book An Astrologer at Work in Late Medieval France: The Notebooks of S. Belle, which has just been published by Brill in the series Time, Astronomy, and Calendars. This book was based on her $\mathrm{PhD}$ research, which she pursued at the Warburg Institute, having completed a master's degree at Universidade Nova in Lisbon on the topic of Vir Sapiens Dominabitur Astris: Astrological Knowledge and Practices in the Portuguese Medieval Court (King João I to King Afonso V). Before reentering academic life she had written (largely in conjunction with her partner, Luís Ribeiro) major works on the practice of contemporary traditional astrology: their Tratado das Esferas (English edition: On the Heavenly Spheres) went through various editions, from 2007 onwards, and helped to educate a generation of traditional astrologers. They were significant contributors to the knowledge of the role of astrology in Portugal and an astrological analysis of the history of Portugal, Astrologia Real: A História de Portugal à Luz da Astrologia (2004). Helena's book An Astrologer at Work explores the interests of the late fifteenth-century astrologer S. (Simon?) Belle and his working methods through a detailed analysis of two notebooks that he compiled. These include scores of horoscopes, some historical but others drawn up by himself for the French nobility and for members of his family, as well as an almanac with marginal notes on the weather and political events, and excerpts from astrological manuals, in Latin and French. It provides a fascinating insight 
into the day-to-day activities of an astrologer and shows how theory (which we know from a host of manuscripts and early printed books) was put into practice. Helena had reliable knowledge of the theory and practice of the traditional astrology used by Belle, a knowledge she was able to use in several articles interpreting horoscopes, interrogations, and choosing times, as well as in the sub-branches of astrological medicine and astrological geography. Had she lived longer she would have been able to apply her knowledge to a much wider field: all the astrological manuscripts in Portuguese libraries, worldwide astrological geography, and a website, set up with Luís Ribeiro and called the Astra Project, dedicated to the study of the history of Western astrological doctrines, techniques, and practices from antiquity to the early modern period, which includes more than $5^{\circ}$ interviews with historians of astrology and related subjects (http://theastraproject.org/adastra/).

It is hoped that those who knew Helena will continue the work that she inaugurated and preserve her memory, especially within the field of premodern astrology.

21 June 2021

\section{Charles Burnett}

Warburg Institute, University of London, London, United Kingdom charles.burnett@sas.ac.uk 